Abstracta Iranicacta Iranica

Revue bibliographique pour le domaine irano-aryen

Volume 32-33 | 2013

Comptes rendus des publications de 2009-2010

\title{
Christian Bromberger. Trichologiques-une anthropologie des cheveux et des poils
}

\section{Yoko Suzuki}

\section{(2) OpenEdition}

1 Journals

\section{Édition électronique}

URL : http://journals.openedition.org/abstractairanica/41009

DOI : 10.4000/abstractairanica.41009

ISSN : 1961-960X

Éditeur :

CNRS (UMR 7528 Mondes iraniens et indiens), Éditions de l'IFRI

\section{Édition imprimée}

Date de publication : 1 décembre 2013

ISSN : 0240-8910

\section{Référence électronique}

Yoko Suzuki, "Christian Bromberger. Trichologiques-une anthropologie des cheveux et des poils», Abstracta Iranica [En ligne], Volume 32-33 | 2013, document 447, mis en ligne le 01 juillet 2016,

consulté le 26 septembre 2020. URL : http://journals.openedition.org/abstractairanica/41009; DOI : https://doi.org/10.4000/abstractairanica.41009

Ce document a été généré automatiquement le 26 septembre 2020.

Tous droits réservés 


\title{
Christian Bromberger. Trichologiques-une anthropologie des cheveux et des poils
}

\author{
Yoko Suzuki
}

\section{RÉFÉRENCE}

Christian Bromberger. Trichologiques-une anthropologie des cheveux et des poils.

Bayard, 2010, 256 p.

1 Cet ouvrage résulte de la comparaison interculturelle de la pilosité et de ses traitements et de ses significations dans plusieurs sociétés asiatiques, y compris Iranienne, européennes et américaines. Le texte est allègrement rythmé, finement argumenté (non seulement dans le sens culturel mais également biologique et physique) et solidement documenté; les sujets familiers à tous, des épisodes divertissants accompagnent de belles images; l'ouvrage ouvre la voie à une fine vulgarisation de l'étude d'anthropologie. En même temps, il n'esquive pas la recherche d'une synthèse sur la diversité culturelle de la pilosité : quatre facteurs déterminent en principe l'apparence pileuse, à savoir les relations entre genres, entre soi et les autres, entre soi et l'ordre du monde et entre soi et des tendances esthétiques dominantes.

2 Malgré toutes ses qualités, cet ouvrage cause quelques fois le vertige, pendant même à la fin de la lecture: d'abord, le plat est un peu trop riche pour une digestion facile, ensuite, car il est parfois difficile à appréhender les liaisons entre épisodes, car certains de ceux-ci, d'une grande complexité culturelle, dépassent le cadre du thème de chapitre annoncé autour des quatre principes synthétisés. 


\section{AUTEURS}

YOKO SUZUKI

Paris 